\title{
Induction of IкB- $\zeta$ by Epstein-Barr virus latent membrane protein-1 and CD30
}

\author{
CHIE ISHIKAWA $^{1,2}$, MASACHIKA SENBA ${ }^{3}$ and NAOKI MORI ${ }^{1}$ \\ ${ }^{1}$ Department of Microbiology and Oncology, Graduate School of Medicine, University of the Ryukyus, \\ Nishihara, Okinawa 903-0215; ${ }^{2}$ Transdisciplinary Research Organization for Subtropics and Island Studies, \\ University of the Ryukyus, Nishihara, Okinawa 903-0213; ${ }^{3}$ Department of Pathology, \\ Institute of Tropical Medicine, Nagasaki University, Nagasaki 852-8523, Japan
}

Received July 8, 2015; Accepted August 21, 2015

DOI: $10.3892 /$ ijo.2015.3218

\begin{abstract}
Activation of nuclear factor- $\kappa \mathrm{B}(\mathrm{NF}-\mathrm{\kappa B})$ in Burkitt's lymphoma (BL) and Hodgkin's lymphoma (HL) cells is important in the transformation and development process of these lymphomas. Epstein-Barr virus (EBV) latent membrane protein-1 (LMP-1) and ligand-independent signaling by overexpressed CD30 are known to cause permanent activation of $\mathrm{NF}-\kappa \mathrm{B}$ in lymphomas. However, hyperactivation of NF- $\kappa \mathrm{B}$ triggers cellular senescence and apoptosis. Here, we show that IкB- $\zeta$, an inducible regulator of NF- $\kappa \mathrm{B}$, is constitutively expressed in BL and HL cell lines. In addition, immunohistochemical staining identified nuclear IкB- $\zeta$-positive BL cells, and Hodgkin and Reed-Sternberg cells in lymph nodes. Expression of LMP-1 and CD30 increased IкB- $\zeta$ expression at the transcriptional level. I $\mathrm{KB}-\zeta$ promoter was regulated by activation of the NF- $\kappa \mathrm{B}$-inducing kinase (NIK)/I $\kappa \mathrm{B}$ kinase/NF- $\kappa \mathrm{B}$ pathway via the carboxyl-terminal tumor necrosis factor (TNF) receptor-associated factor (TRAF)interacting regions of LMP-1 and CD30. Interestingly, ІкB- $\zeta$ inhibited NF- $\mathrm{kB}$ activation by LMP-1 and CD30. The results suggest that $\mathrm{NF}-\kappa \mathrm{B}$-induced $\mathrm{I} \kappa \mathrm{B}-\zeta$ negatively modulates NF- $\kappa B$ hyperactivation, resulting in a fine balance that ultimately endows a net evolutionary benefit to the survival of $\mathrm{BL}$ and HL cells.
\end{abstract}

\section{Introduction}

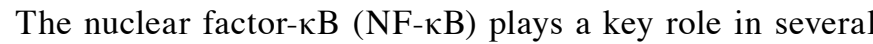
cellular functions, e.g., sustenance of proliferative signaling, evasion of growth suppression, resistance to cell death, ability of replicative immortality, and activation of invasion and

Correspondence to: Professor Naoki Mori, Department of Microbiology and Oncology, Graduate School of Medicine, University of the Ryukyus, 207 Uehara, Nishihara, Okinawa 903-0215, Japan E-mail: naokimori50@gmail.com

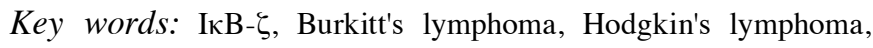
latent membrane protein-1, CD30 metastasis in hematological malignancies (1). The inflammatory process has emerged as a useful marker of cancer progression $(2,3)$. NF- $\kappa \mathrm{B}$ is also involved in the induction of inflammation $(2,3)$. Constitutive activation of NF- $\kappa B$ occurs in most malignant lymphomas and plays a major role in lymphomagenesis and clinical aggressiveness (1). Furthermore, Epstein-Barr virus (EBV) latent membrane protein-1 (LMP-1) and CD30 overexpression have been shown to activate NF- $\mathrm{BB}$ and induce rapidly progressing lymphomas $(1,4)$.

EBV is associated with the development of lymphomas including Burkitt's lymphoma (BL), Hodgkin's lymphoma (HL), diffuse large B-cell lymphoma and natural killer/T-cell lymphoma (5). LMP-1, a transmembrane protein, is essential for in vitro transformation of primary B cells (6). The carboxyl-terminal cytoplasmic domain of LMP-1 contains two carboxyl-terminal activation regions (CTARs); CTAR-1 and CTAR-2. CTAR-1 binds to tumor necrosis factor (TNF) receptor-associated factors (TRAFs) (7), whereas CTAR-2 binds to the TNF receptor-associated death domain (TRADD) (8). NF- $\kappa$ B activation by the CTAR- 1 and CTAR-2 domains of LMP-1 is probably mediated by the binding of TRAFs directly or indirectly to both the CTAR-1 and CTAR-2 domains (7-10).

CD30, a member of the TNF receptor superfamily, is also a transmembrane protein and highly expressed in a variety of lymphoma subsets including HL. Overexpression of CD30 was reported to transduce signals independent of CD30 ligand in HL cells (11). A region of $\sim 100$ amino acids from the carboxyl-terminal region of CD30 is involved in NF- $\mathrm{KB}$ activation (12). TRAFs recognize the carboxyl-terminal D2 and $\mathrm{D} 3$ subdomains of CD30 (12).

Activation of NF- $\mathrm{kB}$ has often been linked to recurrence, poor survival, tumor progression, aggressiveness and chemoresistance (13). However, there are also studies that found $\mathrm{NF}-\kappa \mathrm{B}$ or upstream activators rather to act as tumor suppressors. Contributing to its anticancer property, NF- $\kappa \mathrm{B}$ has been shown to mediate apoptosis in a variety of cell types (14). Overexpression of RelA (p65) caused a cell cycle arrest followed by apoptosis (15). Premature cellular senescence is a terminal cell cycle arrest that can be induced by oncogenic activation or chemotherapy $(16,17)$. NF- $\mathrm{\kappa B}$ also participates in a senescence-associated cytokine response (18). Therefore, 
appropriate regulation of $\mathrm{NF}-\kappa \mathrm{B}$ is critical for the proper function and survival of the cell.

$\mathrm{I} \kappa \mathrm{B}-\zeta$ is an atypical nuclear member of the I $\mathrm{B}$ family (19). The activity of NF- $\kappa \mathrm{B}$ is modulated in a gene-specific manner by $I \kappa \mathrm{B}-\zeta$. In contrast to classical $\mathrm{I} \kappa \mathrm{B}$ proteins that are constitutively expressed and controlled by inducible degradation, $\mathrm{I} \kappa \mathrm{B}-\zeta$ expression is barely detectable in resting cells but is rapidly induced by various pro-inflammatory stimuli, such as lipopolysaccharides and interleukin (IL)- $1 \beta$ (20). I $\mathrm{B}$ B- $\zeta$ regulates $\mathrm{NF}-\kappa \mathrm{B}$ signaling, and reporter analyses suggested that $\mathrm{I} \kappa \mathrm{B}-\zeta$ may act as an inhibitor of NF- $\kappa \mathrm{B}$ (19). In contrast, other studies have reported that $\mathrm{I} \kappa \mathrm{B}-\zeta$ can induce gene expression of individual $\mathrm{NF}-\kappa \mathrm{B}$ target genes (21). A recent study identified the nuclear I $\mathrm{B} \mathrm{B}-\zeta$ to be upregulated in activated B-cell-like subtype of diffuse large B-cell lymphoma (22). We have also reported constitutive expression of $\mathrm{I} \kappa \mathrm{B}-\zeta$ in adult T-cell leukemia cells (23). The hypothesis tested in the present study was that $\mathrm{I} \kappa \mathrm{B}-\zeta$ is induced by LMP-1 and CD30 and that it is also involved in regulation of $\mathrm{NF}-\kappa \mathrm{B}$.

\section{Materials and methods}

Cell culture. Raji and Daudi are EBV-positive BL cell lines. In contrast, BJAB and Ramos are EBV-negative BL cell lines. B95/Ramos is Ramos infected with the B95-8 strain of EBV. L428, KM-H2, HDLM-2 and L540 are HL cell lines. These cell lines were cultured in Roswell Park Memorial Institute (RPMI)-1640 medium supplemented with 10 or $20 \%$ fetal bovine serum (FBS) and antibiotics. Human embryonic kidney 293T cells were cultured in Dulbecco's modified Eagle's medium supplemented with $10 \%$ FBS and antibiotics.

RNA detection. Total RNA was extracted from various cell cultures by TRIzol (Invitrogen Life Technologies, Carlsbad, CA, USA) according to the protocol provided by the manufacturer. The first-strand cDNA was synthesized from $1 \mu \mathrm{g}$ cellular RNA using a PrimeScript RT-PCR kit (Takara Bio Inc., Otsu, Japan) with random primers. The sequences of the primers used are summarized in Table I.

Plasmids, transfection and luciferase assay. Cells (293T) were transfected by the calcium phosphate DNA coprecipitation method. The expression plasmids pSG5-LMP-1, pSG5-LMP-1 $\Delta$ 187-351, pSG5-LMP-1 3449 and pSG5LMP-1 $\Delta$ 194-386 were previously described (24,25). For CD30 expression, the plasmids wild-type human CD30 (pME-hCD30) and its mutant $[\mathrm{pCR}-\mathrm{hCD} 30(\Delta 95)]$ were used (12). The wildtype and various mutants of I $\mathrm{B}-\zeta$, and pcDNA3-RelA were described previously $(26,27)$. The dominant-negative mutants

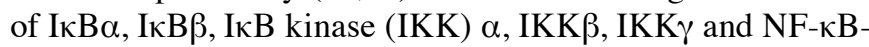
inducing kinase (NIK) have been previously described (28-31). The plasmid for truncated TRAF2 protein with retention of only the TRAF domain, $\triangle \mathrm{TRAF} 2$, has been described previously (32). The human $\mathrm{I} \kappa \mathrm{B}-\zeta$ promoter-luciferase gene constructs have already been described $(23,33)$. The single and combined internal deletion mutants of $\mathrm{NF}-\kappa \mathrm{B}$ sites were constructed by deletion of the $\mathrm{NF}-\kappa \mathrm{B}$ sites of the plasmid

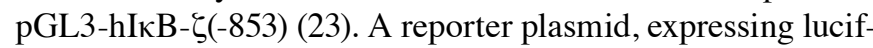
erase through a minimal promoter linked to five copies of the typical $\mathrm{NF}-\kappa \mathrm{B}$ responsive element from the $I L-2$ receptor $\alpha$ chain $(I L-2 R \alpha)$ gene ( $\kappa \mathrm{B}-\mathrm{LUC})$, was used to measure the $\mathrm{NF}-\kappa \mathrm{B}$ transcription competence (34). Two copies of the IL-8 activator protein-1 (AP-1) binding site were inserted upstream of the IL-8 enhancer-less core promoter linked to luciferase gene (AP-1-LUC) (35). Plasmids containing the IL-8 promoter $(-133$ to +44 bp) and the IL-6 promoter $(-225$ to +14 bp) linked to luciferase expression vectors were constructed from luciferase expression vectors $(35,36)$. Bcl-3 luciferase reporter construct was described previously (37). In all cases, phRL-TK was cotransfected to correct for transfection efficiency. After $24 \mathrm{~h}$, luciferase assays were conducted using the dual luciferase reporter system (Promega Corp., Madison, WI, USA), in which the relative luciferase activity was calculated by normalizing transfection relative to the Renilla luciferase activities. Data were expressed as mean \pm SD of three experiments.

Preparation of nuclear extracts and electrophoretic mobility shift assay (EMSA). Nuclear proteins were extracted and transcription factors bound to specific DNA sequences were examined by EMSA, as previously described (38). The top strand sequences of the oligonucleotide probes or competitors were as follows: for the NF- $\kappa \mathrm{B}$ element $(\kappa \mathrm{B} 1)$ of the $I \kappa B-\zeta$ gene, 5'-GATCCGACGGGAATGTCCGGGACT-3'; for the mutated $\kappa$ B1 sequence, 5'-GATCCGACGtGtATGaCCGGG ACT-3'; for the NF- $\kappa \mathrm{B}$ element $(\kappa \mathrm{B} 2)$ of the $I \kappa B-\zeta$ gene, 5'-GATCGGTCTGGGAATTTCCAGTG-3'; for the mutated кB2 sequence, 5'-GATCGGTCTGtGtATaaCCAGTG; for the $\mathrm{NF}-\kappa \mathrm{B}$ element of the $I L-2 R \alpha$ gene, 5'-GATCCGGCAG $\underline{G G G}$ AATCTCCCTCTC-3'; and for the AP-1 element of the $I L-8$ gene, 5'-GATCGTGATGACTCAGGTT-3'. The above underlined sequences are the $\mathrm{NF}-\kappa \mathrm{B}$ and AP-1 binding sites, respectively. The sites of mutation are indicated in lowercase letters. In competition experiments, the nuclear extract was pre-incubated with 100-fold excess of unlabeled oligonucleotides for $15 \mathrm{~min}$. To identify $\mathrm{NF}-\kappa \mathrm{B}$ proteins in the DNA-protein complex shown by EMSA, we used antibodies specific for various $N F-\kappa B$ family proteins, including $\mathrm{p} 50$, RelA, c-Rel, p52 and RelB (Santa Cruz Biotechnology Inc., Santa Cruz, CA, USA). These antibodies were incubated with the nuclear extracts for $45 \mathrm{~min}$ at room temperature before incubation with radiolabeled probes.

Immunohistochemical analysis. Lymph node biopsy samples were obtained from patients with BL and HL. IкB- $\zeta$ immunohistochemistry was performed using an anti-IкB- $\zeta$ antibody (Cell Signaling Technology, Inc., Beverly, MA, USA) after pretreatment of deparafinized tissue sections with ready-to-use proteinase K (Dako, Carpinteria, CA, USA). The sections were counterstained with methyl green, hydrated in ethanol, cleaned in xylene and mounted. Informed consent was obtained from all tissue donors.

\section{Results}

Upregulated $I \kappa B-\zeta$ expression in $B L$ and $H L$. To investigate the role of $\mathrm{I} \kappa \mathrm{B}-\zeta$ in the pathogenesis of $\mathrm{BL}$ and $\mathrm{HL}$, we assessed $\mathrm{I} \kappa \mathrm{B}-\zeta$ mRNA expression levels in established $\mathrm{BL}$ and $\mathrm{HL}$ cell lines using reverse-transcription polymerase chain reaction (RT-PCR). We found that I $\mathrm{B}-\zeta$ mRNA expression was limited to EBV-infected BL cell lines but not in uninfected 
A

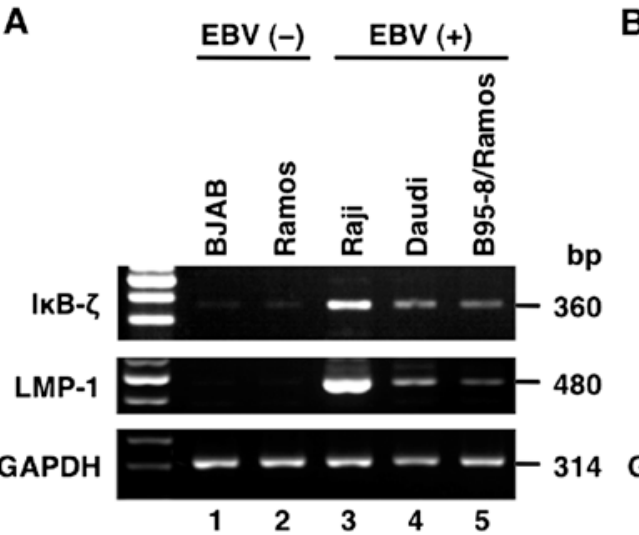

B

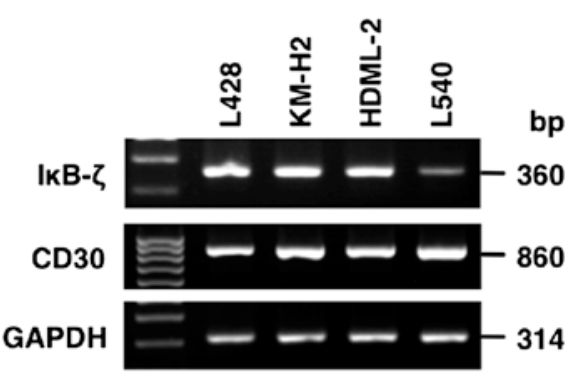

C
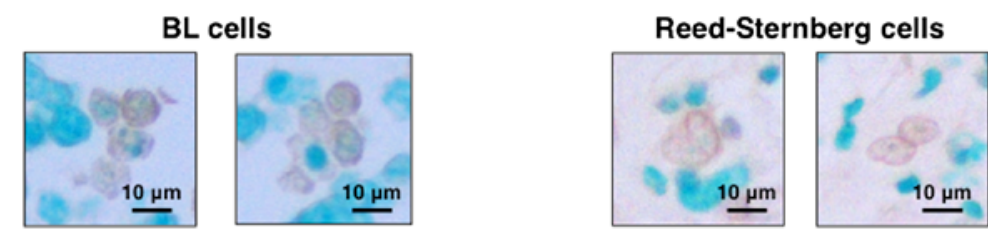

Figure 1. Expression of IкB- $\zeta$ in BL and HL cells. (A) RT-PCR analysis of the indicated genes expression in EBV-negative (lanes 1 and 2) and -positive BL cell lines (lanes 3-5). (B) RT-PCR analysis of expression of the indicated genes in HL cell lines. (C) Immunohistochemical staining of IKB- $\zeta$ in BL and HL lymph nodes. Tissue biopsy sections were stained with anti-IкB- $\zeta$ antibody. Tissue sections were counterstained using methyl green. Magnification, $\mathrm{x} 1,200$.

Table I. Primer sequences.

\begin{tabular}{lll}
\hline Gene name & \multicolumn{1}{c}{ Forward (5') } & \multicolumn{1}{c}{ Reverse (3') } \\
\hline IkB- $\zeta$ & GGAGCTTTTACTGAAGAATAAGA & ATCTGTTCTCCCACAGGGCCATC \\
LMP-1 & GTGACTGGACTGGAGGAGCC & GAGGGAGTCATCGTGGTGGTG \\
CD30 & CTGTGTCCCCTACCCAATCT & CTTCTTTCCCTTCCTCTTCCA \\
IL-6 & ATGAACTCCTTCTCCACAAGC & CTACATTTGCCGAAGAGCCCTCAGGCTGGACTG \\
IL-8 & ATGACTTCCAAGCTGGCCGTG & TTATGAATTCTCAGCCCTCTTCAAAAACTTCTC \\
GAPDH & GCCAAGGTCATCCATGACAACTTTGG & GCCTGCTTCACCACCTTCTTGATGTC \\
\hline
\end{tabular}

cells (Raji, Daudi and B95-8/Ramos) (Fig. 1A). On the other

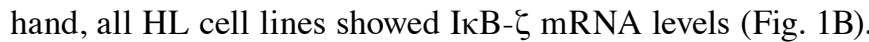
All EBV-infected BL cell lines and HL cell lines constitutively expressed LMP-1 and CD30, respectively (Fig. 1A and B). Immunohistochemical staining of BL cells, and Hodgkin and Reed-Sternberg cells in lymph nodes showed abundant IкB- $\zeta$ protein in the nuclei of these cells (Fig. 1C).

LMP-1 and CD30 induce I $\kappa B-\zeta m R N A$ expression. To investigate the induction of $\mathrm{I} \kappa \mathrm{B}-\zeta$ in $\mathrm{BL}$ and HL, we performed transient expression assays using mammalian expression vectors for LMP-1 and CD30 in 293T cells. After the transfection, RNA was extracted from the cells and the I $\kappa \mathrm{B}-\zeta$ mRNA levels were analyzed by RT-PCR. I $\kappa$ B- $\zeta$ mRNA induction was observed at 48 and $24 \mathrm{~h}$ after LMP-1 and CD30 transfection, respectively. In contrast, $\mathrm{I} \kappa \mathrm{B}-\zeta$ mRNA was hardly detected in cells transfected with empty vectors (pSG5 and pME18S) (Fig. 2A and B).

LMP-1 and CD30 activate the I $\kappa$ B $-\zeta$ promoter. To determine whether LMP-1 and CD30 regulate I $\kappa \mathrm{B}-\zeta$ promoter activity, transient expression assays were performed using the reporter

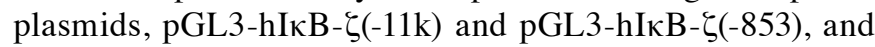

expression vectors for LMP-1 and CD30. LMP-1 and CD30 transactivated the $-11 \mathrm{~kb}$ and $-853 \mathrm{I} \kappa \mathrm{B}-\zeta$ promoter fragments, but this effect was lost in pGL3-basic. LMP-1 and CD30 induced relative levels of $\mathrm{I} \kappa \mathrm{B}-\zeta$ promoter-directed luciferase expression in a dose-dependent manner, suggesting that LMP-1 and CD30 functionally activate minimum $\mathrm{I} \kappa \mathrm{B}-\zeta$ promoter between -853 and -17 bp (Fig. 2C and D).

Importance of carboxyl-terminal regions of LMP-1 and CD30 for $I \kappa B-\zeta$ promoter activation. To map the regions in the LMP-1 and $\mathrm{CD} 30$ proteins that mediate activation of $\mathrm{I} \kappa \mathrm{B}-\zeta$ promoter, LMP-1 and CD30 mutants were expressed and their effect on I $\mathrm{B}-\zeta$ promoter activity was investigated. The LMP-1 mutants used included LMP-1 $\Delta 187-351$ (which contains only CTAR-2 in the carboxyl-terminus), LMP-1 $\Delta 349$ (which lacks CTAR-2) and LMP-1 $\Delta$ 194-386 (in which the entire carboxyl-terminal cytoplasmic region is deleted) (Fig. 3A). In cells that expressed CTARs-free LMP-1 $\Delta 194-386$, I B $-\zeta$ promoter activity was not increased. In contrast, activation of pGL3-hIкB- $\zeta(-11 \mathrm{k})$ and pGL3-hIкB- $\zeta(-853)$ was observed by both CTAR-1-free LMP-1 $\Delta 187-351$ and CTAR-2-free LMP-1 $\Delta 349$, although to a lesser extent than by wild-type LMP-1 (Fig. 3B, lower panel). These results suggest that LMP-1 activates I $\mathrm{LB}-\zeta$ expression 
A
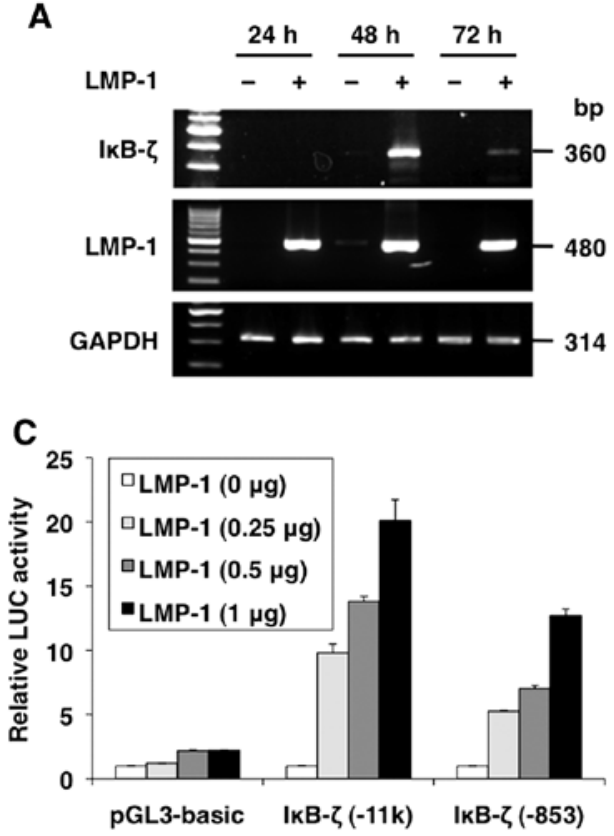

B
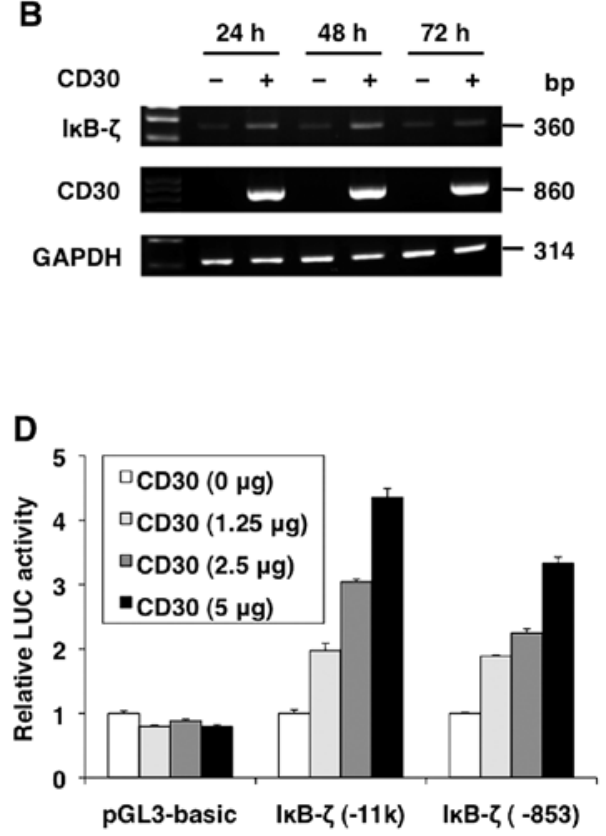

Figure 2. Ectopic expression of LMP-1 and CD30 induces I $\kappa$ B- $\zeta$ expression at transcriptional level. (A) LMP-1 and (B) CD30 upregulate I $\kappa$ B- $\zeta$ mRNA expression. Cells (293T) were transfected with plasmids encoding LMP-1 and CD30, or empty vectors. RNA was isolated from cells at the indicated times, and RT-PCR was carried out. (C) LMP-1 and (D) CD30 activate the I $\kappa$ B- $\zeta$ promoter. Cells (293T) were transfected with the indicated I $\kappa$ B- $\zeta$ promoter fragments cloned into pGL3-basic together with increasing amounts of (C) LMP-1 or (D) CD30 expression plasmid. The activities are expressed relative to that of cells transfected with the indicated reporter plasmids and empty vectors, which was defined as 1 . LUC, luciferase.
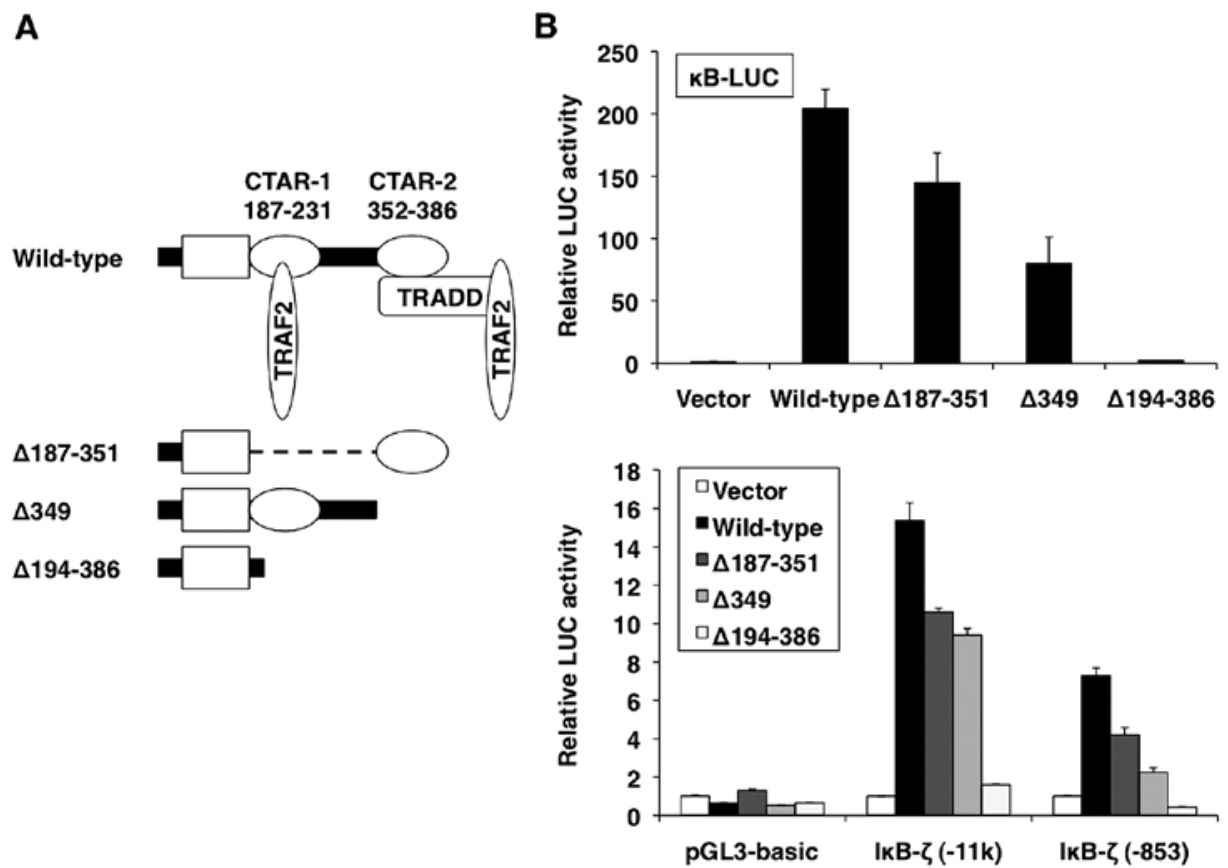

Figure 3. Deletions in CTAR-1 and CTAR-2 abrogate the effect of LMP-1 on IкB- $\zeta$ promoter activity. Cells (293T) were cotransfected with plasmids encoding

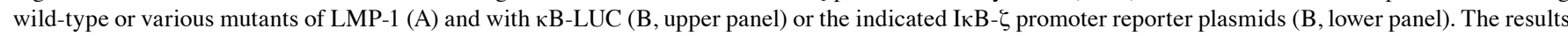
are represented as fold induction by wild-type or mutants of LMP-1 relative to the vector alone.

via the cooperative activity of CTAR-1 and CTAR-2 signaling motifs. As measured in an NF- $\mathrm{B}$-dependent luciferase reporter gene assay, LMP-1 increased NF- $\kappa$ B activation via CTAR-1 and CTAR-2 (Fig. 3B, upper panel).

The carboxyl-terminal region of CD30 is also essential for signal transduction (Fig. 4A) (12). Next, we investigated whether the carboxyl-terminal region of CD30 plays a role in the induction of I $\mathrm{I} \mathrm{B}-\zeta$. As shown in Fig. 4B, lower panel, $\mathrm{I} \kappa \mathrm{B}-\zeta$-driven reporter gene activity was not increased by CD30 $\Delta 95$, which lacks the carboxyl-terminal region of CD30. Notably, the effect of the structural context of the carboxyl-terminal region of LMP-1 and CD30 on IкB- $\zeta$ promoter activation correlated with $\mathrm{NF}-\kappa \mathrm{B}$ activation as reporter analyses by mutant constructs (Figs. 3B and 4B, upper 
A

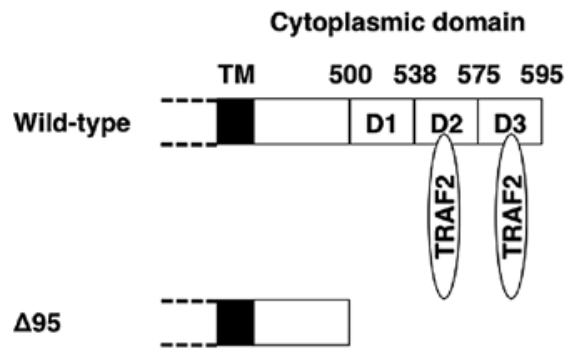

B

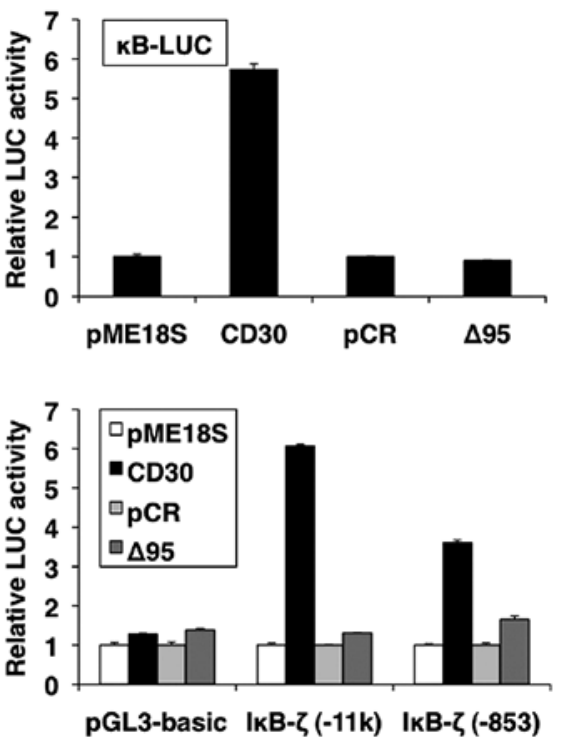

Figure 4. The carboxyl-terminal domain of CD30 is required for its activity. (A) Schematic diagrams of wild-type and mutant CD30 protein. TM, transmembrane domain. (B) Induction of I $\kappa$ B- $\zeta$ transcriptional activity by wild-type and deletion mutant of CD30. Cells (293T) were transfected with wild-type or CD30 mutant and $\kappa \mathrm{B}-\mathrm{LUC}(\mathrm{B}$, upper panel) or the indicated $\mathrm{I} \kappa \mathrm{B}-\zeta$ promoter reporter plasmids (B, lower panel). Negative control vectors pME18S and pCR are used for pME-hCD30 and pCR-hCD30( $\Delta 95)$, respectively.

panels). These results suggest that LMP-1 and CD30 activate $\mathrm{I} \kappa \mathrm{B}-\zeta$ promoter through the $\mathrm{NF}-\kappa \mathrm{B}$ signaling pathway.

LMP-1 and CD30 activate I $\mathrm{B}-\zeta$ promoter activity via the $N F-\kappa B$ signaling pathway. LMP-1 and CD30 are constitutively aggregated pseudo-TNF receptors that activate $\mathrm{NF}-\kappa \mathrm{B}$ through their carboxyl-terminal cytoplasmic domains associated with TRAF2 (7-12). Aggregated TRAF2 activates NIK and its downstream target, the IKK complex, which is composed of two catalytic subunits, IKK $\alpha$ and IKK $\beta$, and a regulatory subunit, IKK $\gamma(39,40)$. The IKK complex phosphorylates the inhibitory I $\mathrm{B}$ proteins, which are bound to $\mathrm{NF}-\kappa \mathrm{B}$ in the cytosol. Their phosphorylation is followed by their degradation, dissociation of NF- $\kappa \mathrm{B}$ from the inhibitors, and $\mathrm{NF}-\kappa \mathrm{B}$ translocation into the nucleus (41). In order to determine the role of TRAF2/NIK/IKK/I $\kappa \mathrm{B}$ proteins in mediating I $\kappa \mathrm{B}-\zeta$ activation induced by LMP-1 and CD30, 293 T cells were cotransfected with LMP-1 or CD30 expression plasmid and plasmids expressing dominant-negative forms of TRAF 2 , NIK, IKK $\alpha$, IKK $\beta$, IKK $\gamma$, I $\kappa B \alpha$ or I $\mathrm{B} \beta \beta$. All dominant-negative mutants reduced $\mathrm{I} \kappa \mathrm{B}-\zeta$ promoter activation by LMP-1 and CD30 (Fig. 5A). These data indicate that the activation of NF- $\kappa \mathrm{B}$ through TRAF2/NIK/IKK plays a role in the activation of $\mathrm{I} \kappa \mathrm{B}-\zeta$ promoter by LMP-1 and CD30.

$N F-\kappa B$ sites in the promoter are essential for the transcriptional upregulation of the $I \kappa B-\zeta$ gene. The human $\mathrm{I} \kappa \mathrm{B}-\zeta$ promoter contains two NF- $\kappa \mathrm{B}$ motifs $(\kappa \mathrm{B} 1$ and $\kappa \mathrm{B} 2)$ (Fig. 5B, top panel) (33). To determine the involvement of $\kappa \mathrm{B} 1$ and $\kappa \mathrm{B} 2$ in the induction of $I \kappa B-\zeta$ gene expression by LMP-1 and CD30, we investigated the activity of $\mathrm{I} \kappa \mathrm{B}-\zeta$ promoter with deletions in $\kappa \mathrm{B} 1$ and $\kappa \mathrm{B} 2$ sites. As shown in Fig. 5B, LMP-1 and CD30

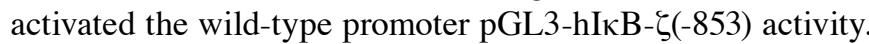
A single deletion of the $\kappa \mathrm{B} 2$ site from the $\mathrm{I} \kappa \mathrm{B}-\zeta$ reporter plasmid ( $\kappa \mathrm{B} 2 \mathrm{D})$ markedly inhibited LMP-1- or CD30-induced transactivation, whereas a single deletion of the $\kappa \mathrm{B} 1$ site $(\kappa \mathrm{B} 1 \mathrm{D})$ resulted in moderate activation. These data indicate that $\mathrm{I} \kappa \mathrm{B}-\zeta$ $\kappa \mathrm{B} 2$ site was necessary for transcription of $\mathrm{I} \kappa \mathrm{B}-\zeta$. Furthermore, double deletions $(\kappa \mathrm{B} 1 / \kappa \mathrm{B} 2 \mathrm{D})$ completely abolished the LMP-1- or CD30-induced transactivation. Expression of RelA is sufficient to induce $\mathrm{I} \kappa \mathrm{B}-\zeta$ expression. The predominant role of $\kappa \mathrm{B} 2$ in the induction of I $\mathrm{I} \mathrm{B}-\zeta$ expression was further supported by the finding that a promoter with a deleted $\kappa \mathrm{B} 2$ site failed to respond to overexpressed RelA (Fig. 5B, bottom panel). In contrast, a promoter with a deleted $\kappa \mathrm{B} 1$ was slightly activated by RelA. Considered together, these data suggest that upregulation of I $\mathrm{KB}-\zeta$ by LMP-1 and CD30 requires both the $\kappa \mathrm{B} 1$ and $\kappa \mathrm{B} 2$ sites of the $\mathrm{I} \kappa \mathrm{B}-\zeta$ promoter.

Since the deletional analysis of the I $\kappa \mathrm{B}-\zeta$ promoter indicated that LMP-1 and CD30 activated transcription through both the $\kappa \mathrm{B} 1$ and $\kappa \mathrm{B} 2$ sites, it was important to identify the nuclear factors that bind to these sites. Using the $\kappa \mathrm{B} 1$ and $\kappa \mathrm{B} 2$ sequences in the $\mathrm{I} \kappa \mathrm{B}-\zeta$ promoter as the probes in EMSA, NF- $\mathrm{B}$ binding was detected in $293 \mathrm{~T}$ cells transfected with LMP-1 (Fig. 6A, lane 2) and CD30 (Fig. 7A, lane 2). In addition, formation of these complexes was competed with excess of unlabeled wild-type $\kappa \mathrm{B} 1, \kappa \mathrm{B} 2$ and consensus IL-2R $\kappa \mathrm{B}$ oligonucleotides (Figs. 6A and 7A, lanes 3, 5 and 7). In contrast, mutated oligonucleotides, $\kappa \mathrm{B} 1$ mut and $\kappa \mathrm{B} 2$ mut, and irrelevant consensus IL-8 AP-1 oligonucleotide, did not compete with the labeled probes (Figs. 6A and 7A, lanes 4, 6 and 8). Supershift analyses demonstrated that the $\kappa B 1$ and $\kappa \mathrm{B} 2$ complexes contained both $\mathrm{p} 50$ and RelA subunits of the $\mathrm{NF}-\kappa \mathrm{B}$ family (Figs. 6A and 7A, lanes 9 and 10). To determine the role of LMP-1 and CD30 on endogenous $N F-\kappa B$ binding to DNA, we measured NF- $\kappa \mathrm{B}$ binding to respective $\mathrm{NF}-\kappa \mathrm{B}$ sites in the $\mathrm{I} \kappa \mathrm{B}-\zeta$ promoter in LMP-1-expressing Daudi cells and CD30-expressing L428 and HDLM-2 cells. As expected, protein complexes bound to both $\kappa \mathrm{B} 1$ and $\kappa \mathrm{B} 2$ sites were detected in nuclear extracts from Daudi, L428 and HDLM-2 cells (Figs. 6B and 7B, lane 1). The specificity of 

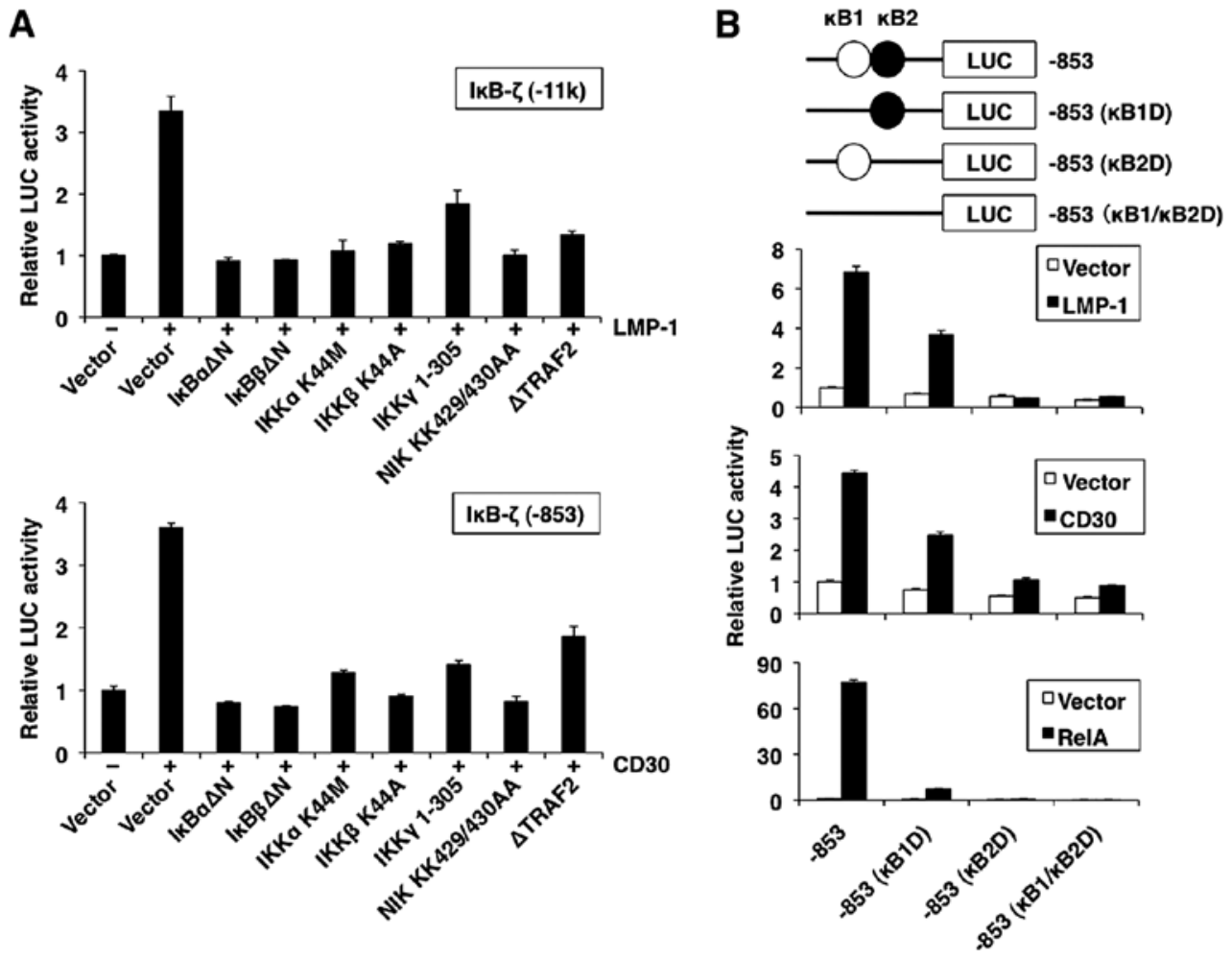

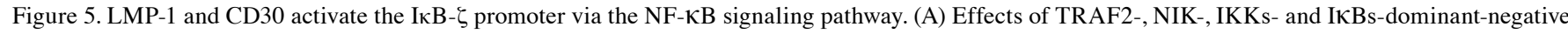

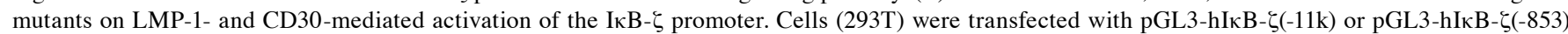
together with LMP-1 or CD30 and the indicated dominant-negative mutants or empty vector. The activities are expressed relative to that of cells transfected

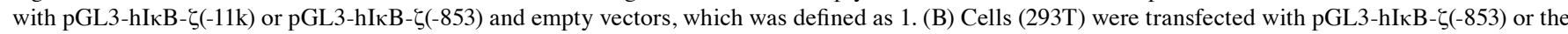
single and combined internal deletion mutants of NF-אB sites, together with either empty vector or expression plasmid for LMP-1, CD30 or RelA. Schematic

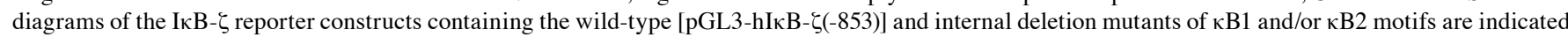
on the top of the figure. The activities are expressed relative to that of cells transfected with pGL3-hIкB- $\zeta(-853)$ and an empty vector, which was defined as 1 .

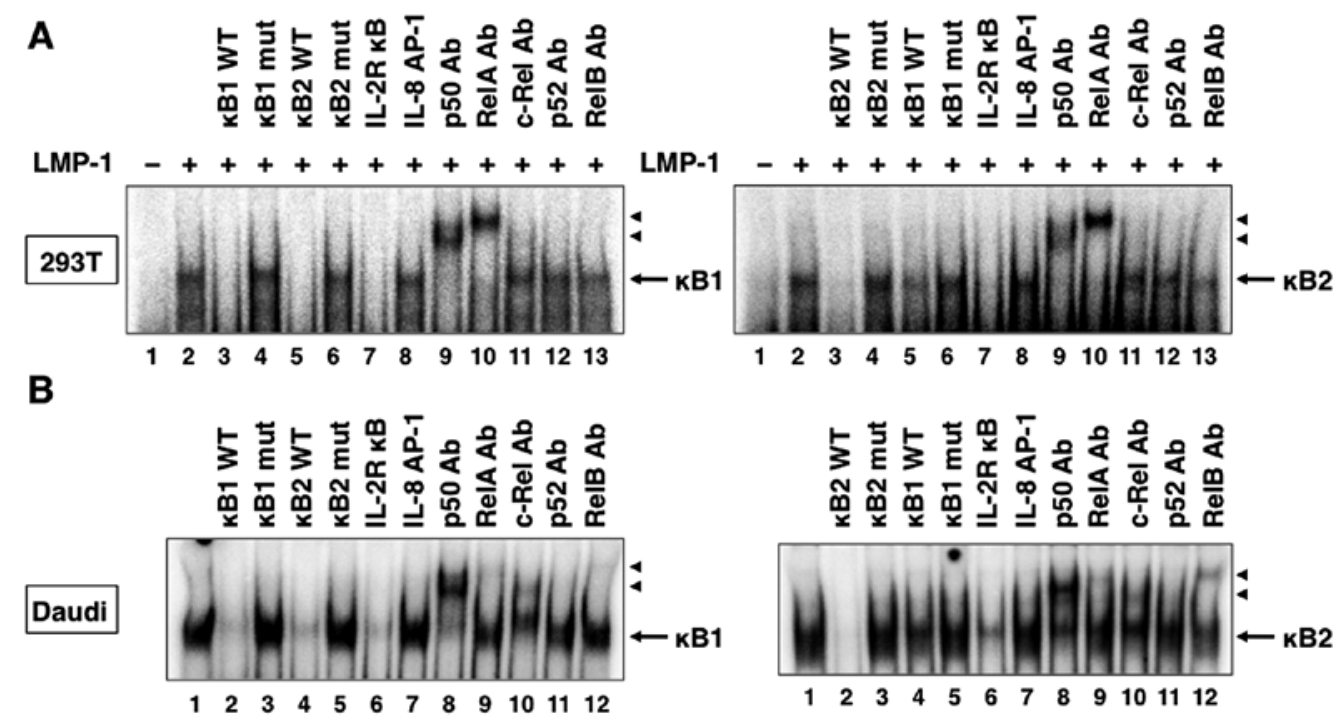

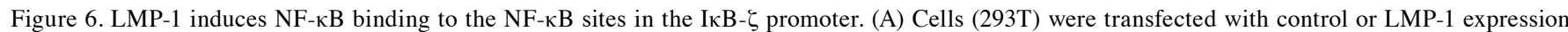
plasmid. Nuclear proteins were extracted $48 \mathrm{~h}$ after transfection. Nuclear extracts from transfected 293T cells (A) or Daudi cells (B) were incubated with the labeled DNA probes representing the IкB- $\zeta \kappa \mathrm{B} 1$ and $\kappa \mathrm{B} 2$ sites. Nuclear extracts were subjected to competition analysis with an excess of unlabeled oligonucle-

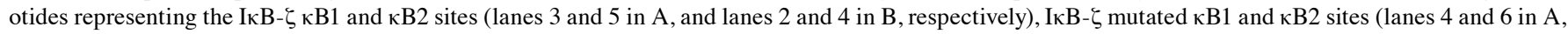
and lanes 3 and 5 in B), a consensus NF-kB site from the IL-2R $\alpha$ promoter (lane 7 in A, and lane 6 in B) or an AP-1 site from the IL-8 promoter (lane 8 in A, and lane 7 in B). Nuclear extracts were also subjected to supershift assays with either no antibody (lane 2 in A, and lane 1 in B) or the indicated antibodies (Ab) (lanes 9-13 in A, and lanes 8-12 in B). Arrows, specific complexes; arrowheads, DNA binding complex supershifted by the antibody.

DNA-protein complexes in these extracts was determined by competition studies using unlabeled competitors. As observed in nuclear extracts from $293 \mathrm{~T}$ cells transfected with LMP-1 and CD30 expression plasmids, unlabeled $\kappa \mathrm{B} 1$ and $\kappa \mathrm{B} 2$ 


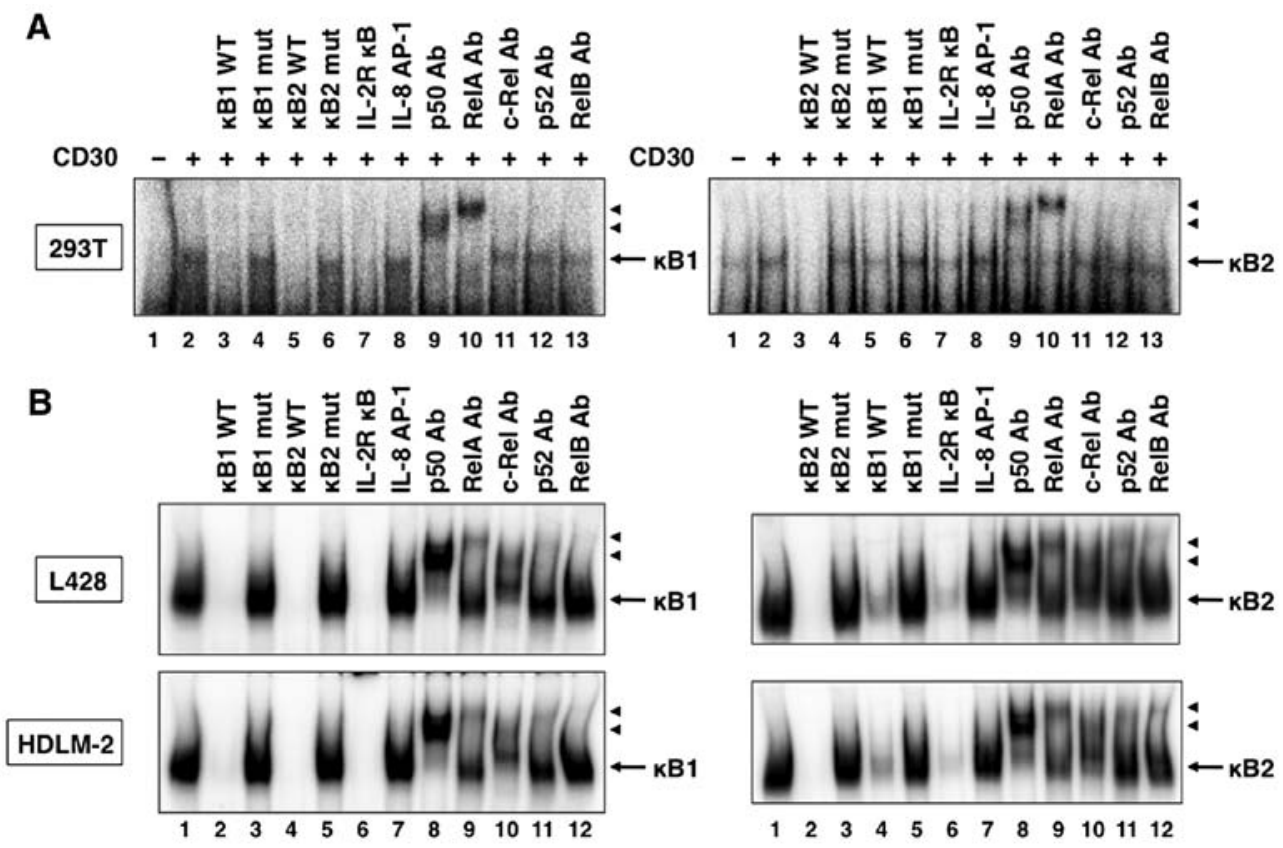

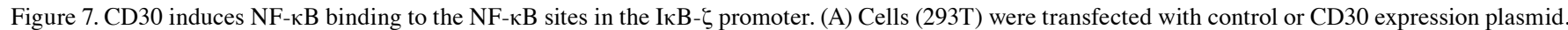
Nuclear proteins were extracted $48 \mathrm{~h}$ after transfection. Nuclear extracts from transfected 293T cells (A), L428 or HDLM-2 cells (B) were incubated with the labeled DNA probes representing the IкB- $\zeta \kappa \mathrm{B} 1$ and $\kappa \mathrm{B} 2$ sites. Nuclear extracts were subjected to competition analysis with an excess of unlabeled oligonucle-

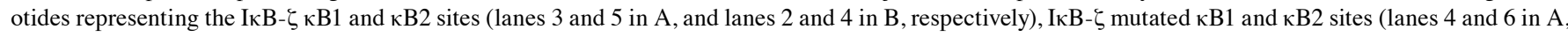
and lanes 3 and 5 in B), a consensus NF- $\mathrm{KB}$ site from the IL-2R $\alpha$ promoter (lane 7 in A and lane 6 in B) or an AP-1 site from the IL-8 promoter (lane 8 in A and lane 7 in B). Nuclear extracts were also subjected to supershift assays with either no antibody (lane 2 in A and lane 1 in B) or the indicated antibodies (Ab) (lanes 9-13 in A, and lanes 8-12 in B). Arrows, specific complexes; arrowheads, DNA binding complex supershifted by the antibody.

A
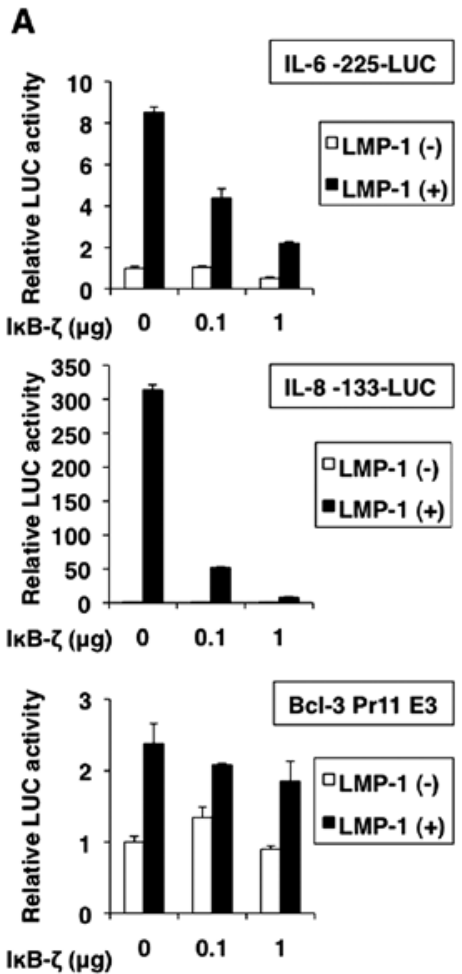

B
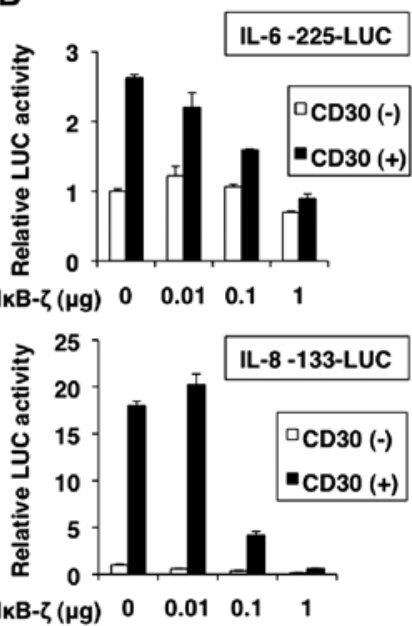

C
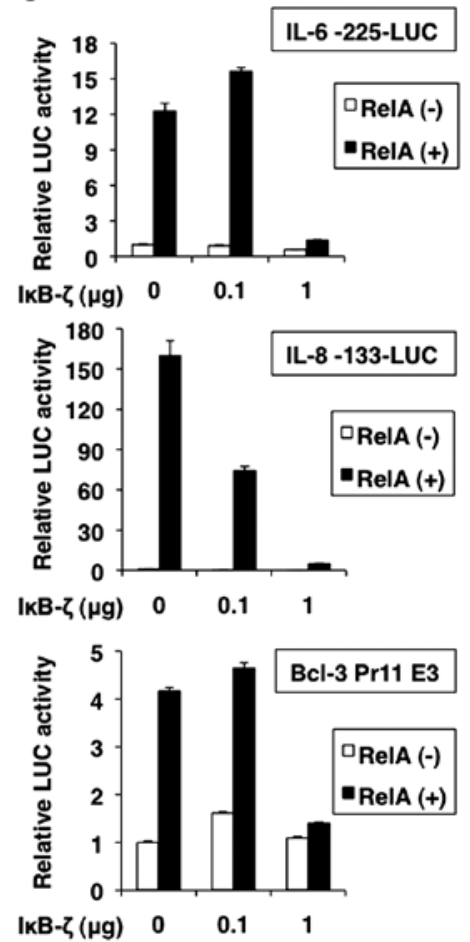

Figure 8. Cotransfection of IкB- $\zeta$ inhibits the LMP-1-, CD30- and RelA-mediated transactivation of IL-6, IL-8 and Bcl-3 promoters. Cells (293T) were transfected with IL-6, IL-8 or Bcl-3 promoter reporter plasmid together with the expression plasmid for LMP-1 (A), CD30 (B) or RelA (C), and the indicated amounts of $\mathrm{I} \kappa \mathrm{B}-\zeta$ expression plasmid. The activities are expressed relative to that of cells transfected with the indicated reporter plasmids and empty vectors, which was defined as 1 .

oligonucleotides, and consensus NF- $\mathrm{B}$ site from the IL- $2 \mathrm{R} \alpha$ promoter, but not the mutated $\kappa \mathrm{B} 1$ and $\kappa \mathrm{B} 2$ oligonucleotides, and consensus AP-1 element, efficiently competed with the labeled probes (Figs. 6B and 7B, lanes 2-7). Antibodies 


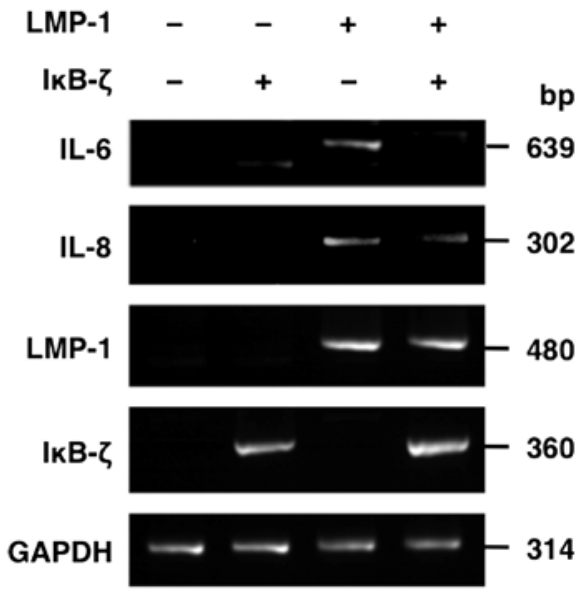

Figure 9. Cotransfection of IkB- $\zeta$ inhibits the LMP-1-induced expression of IL-6 and IL-8. Cells (293T) were transfected with the expression plasmid for LMP-1 together with the IкB- $\zeta$ expression plasmid. RNA was extracted $48 \mathrm{~h}$ after transfection. The mRNA expression level of the indicated genes was analyzed by RT-PCR.

against p50, RelA, c-Rel and RelB induced a supershift of the DNA-protein complexes in nuclear extracts of Daudi cells (Fig. 6B, lanes 8-10 and 12), whereas the $\kappa \mathrm{B} 1$ and $\kappa \mathrm{B} 2$ complexes contained p50, RelA, c-Rel, p52 and RelB in nuclear extracts of L428 and HDLM-2 cells (Fig. 7B, lanes 8-12). Taken together, the results indicate that $\mathrm{NF}-\kappa \mathrm{B}$ proteins bind to both $\kappa \mathrm{B}$ elements of the $\mathrm{I} \kappa \mathrm{B}-\zeta$ promoter in Daudi, L428 and HDLM-2 cells.

A

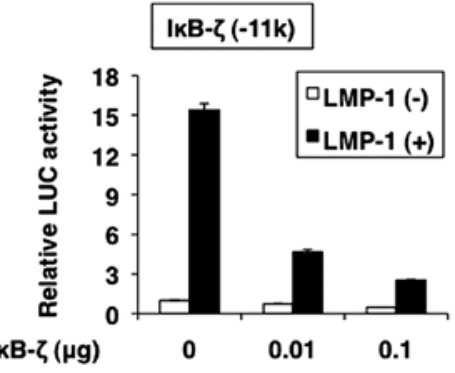

B

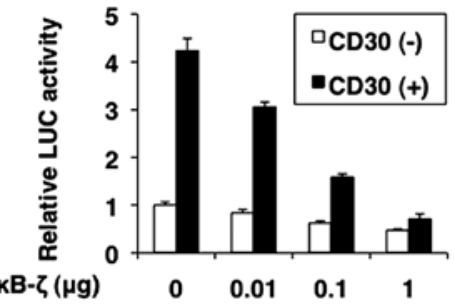

C

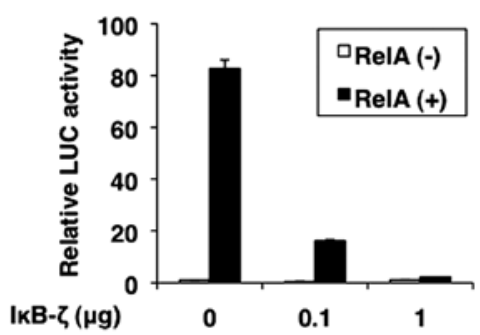

Role of $I \kappa B-\zeta$ in the expression of $N F-\kappa B$ target genes. Unlike other I $\mathrm{B}$ family members, I $\kappa \mathrm{B}-\zeta$ has dual opposite functions on the expression of different cellular genes activated by $\mathrm{NF}-\kappa \mathrm{B}(19-21,27)$. To identify the genes whose expression is regulated by $\mathrm{I} \kappa \mathrm{B}-\zeta$, we examined the promoter activities of several NF- $\mathrm{BB}$ target genes in 293T cells transfected

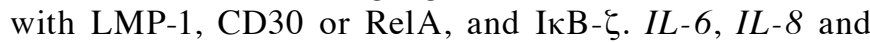
$\mathrm{Bcl}-3$ genes are known to be activated by NF- $\mathrm{BB}(35-37)$. Luciferase reporter analyses indicated that promoters of IL-6, IL-8 and Bcl-3 were activated by transfection of LMP-1, CD30 and RelA as expected (Fig. 8A-C). Cotransfection of I $\kappa$ B $-\zeta$ dose-dependently inhibited the LMP-1-, CD30- and RelA-induced activation of promoters of IL-6, IL-8 and Bcl-3. In addition, we analyzed whether I $\mathrm{I} \mathrm{B}-\zeta$ overexpression leads to downregulation of known NF- $\kappa \mathrm{B}$ targets on mRNA level. To this end, we determined the effect of $\mathrm{I} \kappa \mathrm{B}-\zeta$ overexpression on IL-6 and IL-8 mRNA expression in the presence of LMP-1 by RT-PCR. These analyses demonstrated that IL- 6 and IL-8 mRNA levels were downregulated after I $\kappa \mathrm{B}-\zeta$ overexpression (Fig. 9), suggesting that $\mathrm{I} \kappa \mathrm{B}-\zeta$ plays a role in negatively regulating $\mathrm{NF}-\kappa \mathrm{B}$ targets.

We also analyzed the effect of I $\kappa \mathrm{B}-\zeta$ overexpression on the activation of its promoter induced by LMP-1, CD30 and RelA. LMP-1-, CD30- and RelA-induced I $\mathrm{B}-\zeta$ promoter activation was dose-dependently repressed by IкB- $\zeta$ overexpression (Fig. 10A-C). Thus, I $\mathrm{B}$ B- $\zeta$ can repress its own transcription. I $\mathrm{B}-\zeta$ expression itself was regulated by $\mathrm{NF}-\kappa \mathrm{B}$, suggesting that its activity is controlled through a negative feedback loop.

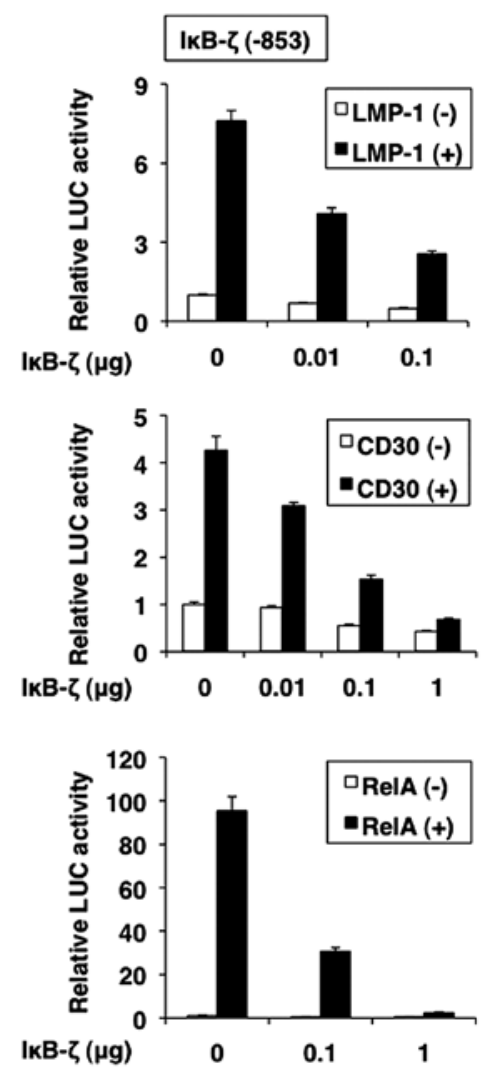

Figure 10. IкB- $\zeta$ represses activated transcription of its own promoter. Cells (293T) were transfected with the indicated I $\kappa \mathrm{B}-\zeta$ promoter reporter plasmids together with the expression plasmid for LMP-1 (A), CD30 (B) or RelA (C), and the indicated amounts of I $\kappa$ B- $\zeta$ expression plasmid. The activity is expressed relative to that of cells transfected with the indicated reporter plasmids and empty vectors, which was defined as 1. 

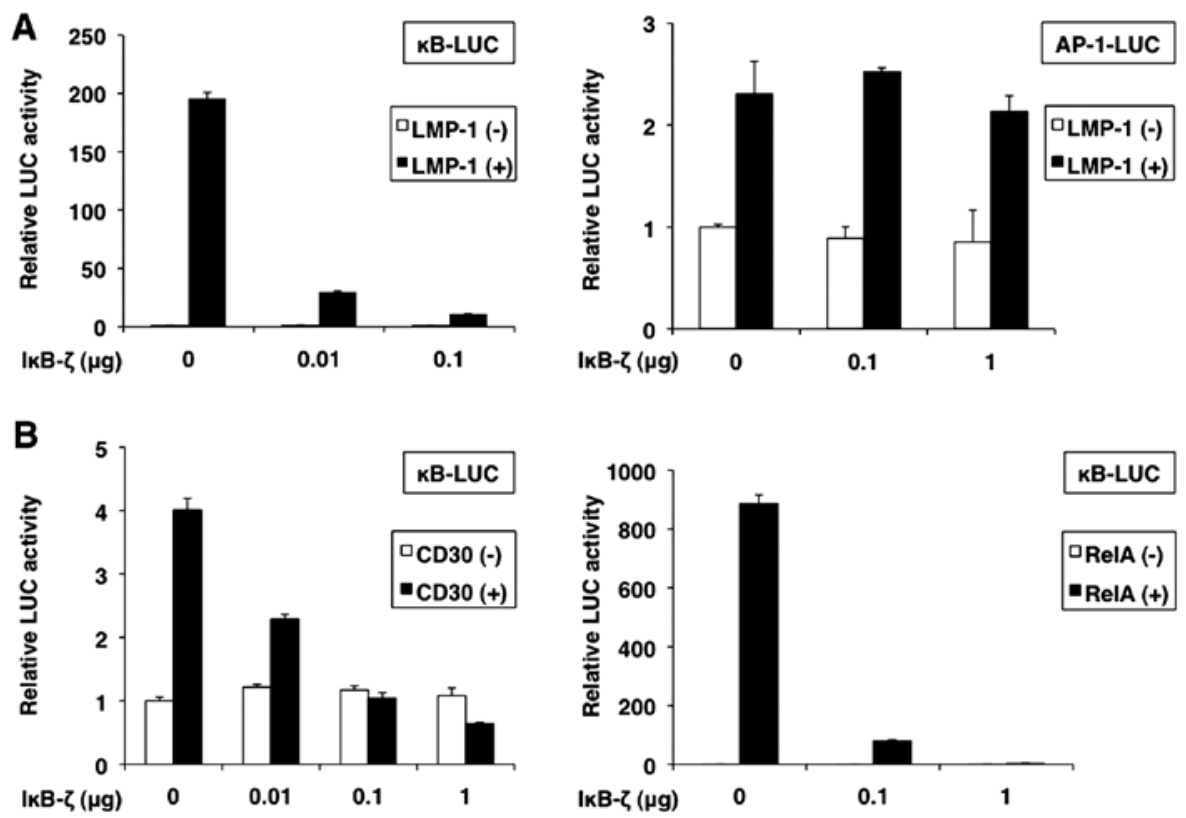

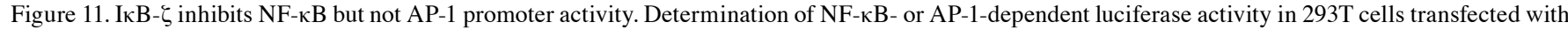
$\kappa \mathrm{B}-\mathrm{LUC}$ or AP-1-LUC, together with the expression plasmid for LMP-1 (A), CD30 or RelA (B), and the indicated amounts of IкB- $\zeta$ expression plasmid. The activity was expressed relative to that of cells transfected with the indicated reporter plasmids and empty vectors, which was defined as 1.
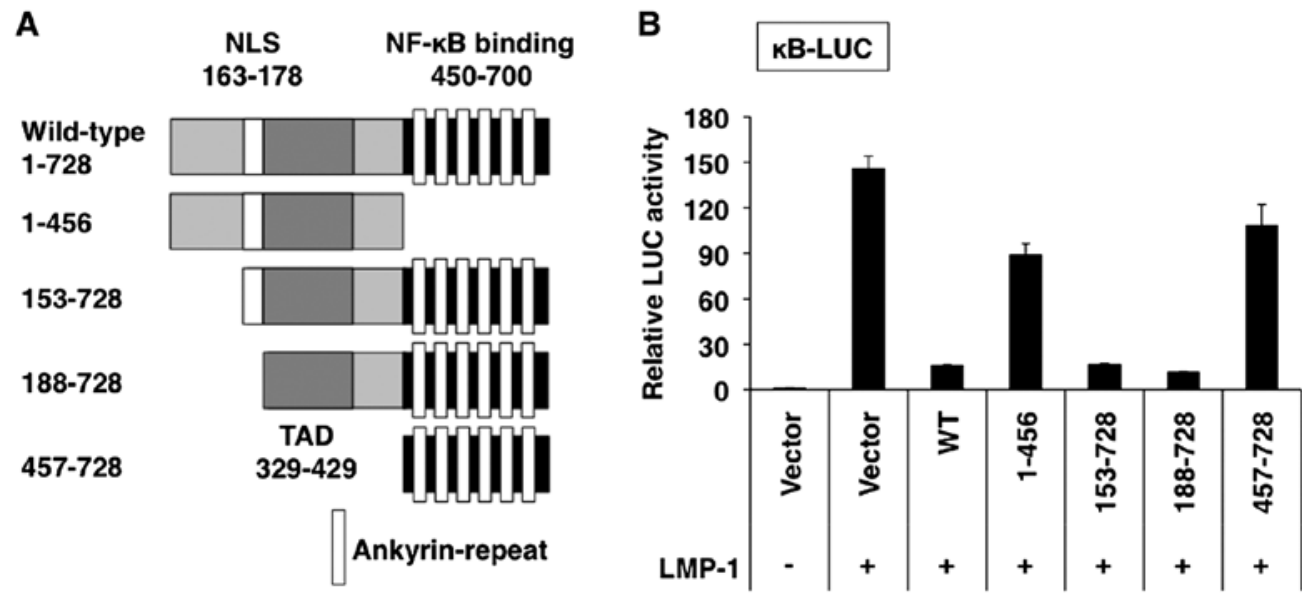

Figure 12. The internal fragments and carboxyl-terminal ankyrin-repeats of IкB- $\zeta$ have transcriptional inhibitory activity. (A) Schematic diagram of the

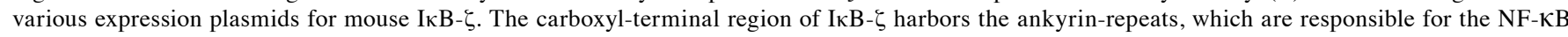
binding. The amino-terminal region contains a nuclear localization signal (NLS) and a transcriptional activation domain (TAD). (B) IкB- $\zeta$ functional domains responsible for inhibition of LMP-1-induced NF-kB activity. Cells (293T) were cotransfected with expression plasmid for LMP-1 and an expression plasmid for

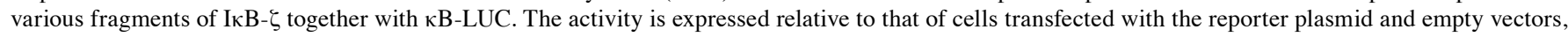
which was defined as 1.

To confirm the role of I $\kappa \mathrm{B}-\zeta$ in NF- $\kappa \mathrm{B}$ activity, we transfected 293 T cells with IкB- $\zeta$, and LMP-1, CD30 or RelA, and measured the activity of $\kappa B$-LUC, an NF- $\kappa B$ reporter construct. As expected, we found that NF- $\kappa \mathrm{B}$ reporter activity induced by LMP-1, CD30 and RelA was repressed by IкB- $\zeta$ overexpression in a dose-dependent manner (Fig. 11A, left panel, and 11B). However, the results showed that IкB- $\zeta$ did not affect AP-1 reporter activity induced by LMP-1 (Fig. 11A, right panel).

Mutants of $I \kappa B-\zeta$ truncated from the amino- and carboxyl-termini were expressed in the presence of LMP-1 in 293T cells, and the NF- $\kappa$ B reporter activity was measured (Fig. 12A). The amino-terminal truncated mutants (153-728 and 188-728) as well as the full-length I $\mathrm{B}-\zeta$ (1-728), showed inhibitory activities against LMP-1-induced NF- $\kappa \mathrm{B}$ activation, whereas the mutants consisting of the amino-terminus to amino acid 456 (1-456) and the amino-terminal truncated mutant (457-728) exhibited less activity than the full-length IкB- $\zeta(1-728)$ (Fig. 12B). These results indicate that the region between amino acids 188-728 harbors a domain with transcriptional inhibitory activity.

\section{Discussion}

Constitutive activation of the oncogenic NF- $\kappa \mathrm{B}$ pathway is a characteristic hallmark of several lymphoma subtypes (1). 


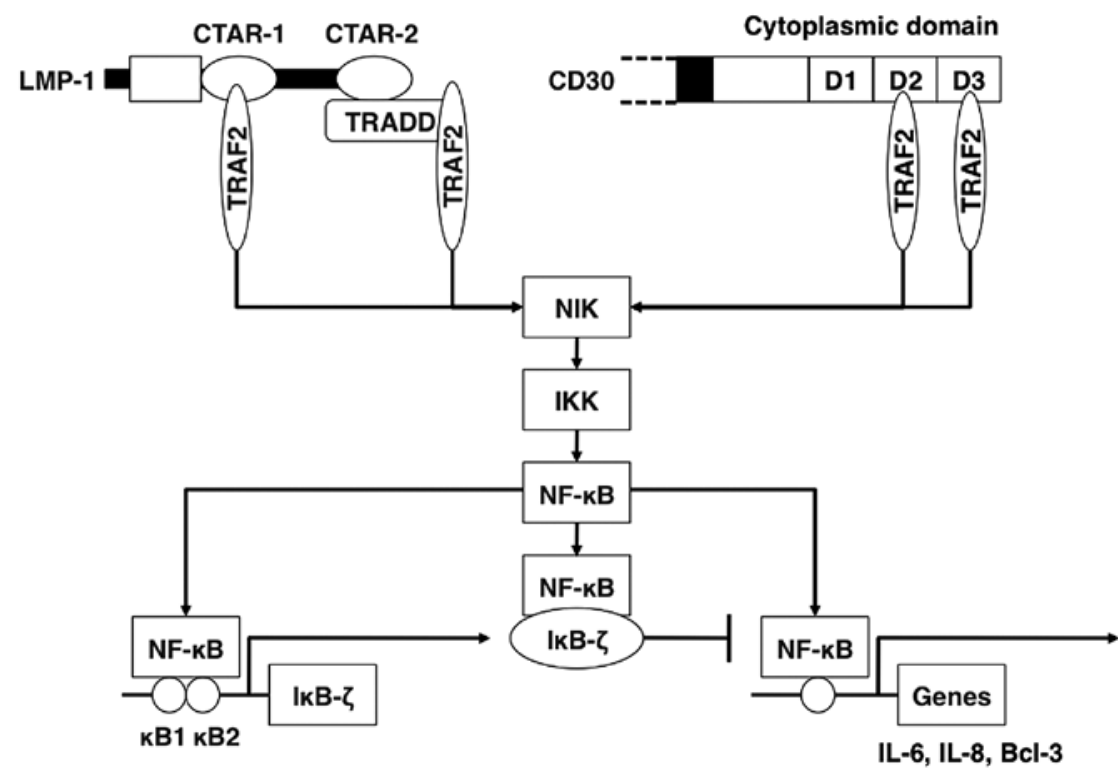

Figure 13. Hypothetical model for NF-кB-IкB- $\zeta$ autoregulatory loop in BL and HL.

EBV LMP-1 and CD30 have been demonstrated to activate the $N F-\kappa B$ signaling pathways in lymphomas (1). It has become increasingly clear that activation of NF- $\kappa \mathrm{B}$ is not only controlled in the cytoplasm but, presumably even more importantly, also modulated in the nucleus. The nuclear $\mathrm{I} \kappa \mathrm{B}$ family member I $\mathrm{B}-\zeta$ acts a multifaceted modulator of $\mathrm{NF}-\kappa \mathrm{B}$ activity (20). We demonstrated high I $\kappa \mathrm{B}-\zeta$ expression in LMP-1-expressing BL and CD30-expressing HL cell lines. Nuclear I $\mathrm{B}-\zeta$ expression was also shown in lymph nodes from patients with BL and HL by immunohistochemical staining.

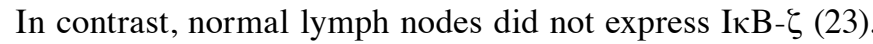
Due to the potential significance of these observations on the two lymphoma types, we investigated the transcriptional basis for LMP-1- and CD30-induced IผB- $\zeta$ expression. Our results demonstrated that LMP-1 and CD30 activate I $\kappa \mathrm{B}-\zeta$ transcription primarily through two NF- $\mathrm{BB}$ sites in its promoter. The TRAF/NIK/IKK pathway also contributed to the activation of the I $\kappa \mathrm{B}-\zeta$ promoter as shown by the use of dominant-negative constructs. These data provide the molecular basis for the observed LMP-1- and CD30-induced overexpression of

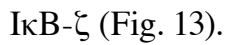

We next considered the consequence of I $\mathrm{I} B-\zeta$ overexpression in BL and HL cells. The results showed that $\mathrm{I} \kappa \mathrm{B}-\zeta$ potently repressed the LMP-1- and CD30-induced NF- $\mathrm{NB}$ activation in a negative feedback loop, suggesting the presence of an NF- $\kappa \mathrm{B}-\mathrm{I} \kappa \mathrm{B}-\zeta$ autoregulatory loop (Fig. 13). $\mathrm{I} \kappa \mathrm{B}-\zeta$ associates with the $\mathrm{NF}-\kappa \mathrm{B}$ subunit $\mathrm{p} 50$ and $\mathrm{I} \kappa \mathrm{B}-\zeta$ inhibits the DNA binding of the RelA/p50 heterodimer and the p50/p50 homodimer (19). Negative autoregulatory loop provides an effective mechanism for the control of $N F-\kappa B$ activation. The inhibitory roles of the negative autoregulatory loop on $\mathrm{NF}-\kappa \mathrm{B}$-mediated transcription may be critical in fine tuning the balance between activators and suppressors of tumors to maintain lymphoma in vivo. The relatively high frequency of expression of another nuclear I $\mathrm{B}$ family protein, Bcl-3, was reported in some lymphoma types (42). Like I $\mathrm{KB}-\zeta$, Bcl-3 is a multifaceted modulator of the NF- $\kappa$ B activity and has multiple functions (43). Because the ankyrin-repeats of $\mathrm{I} \kappa \mathrm{B}-\zeta$ are homologous to that of Bcl-3 (20), Bcl-3 may act as a competitor for I $\mathrm{I} B-\zeta$, or vice versa. Appropriate cellular responses are regulated by the control of precise balance between accelerators, brakes and steering wheels to maintain homeostasis following environmental change (20). Elucidation of the precise mechanism that determines the atypical nuclear $\mathrm{I} \kappa \mathrm{B}$ family effects should be paramount to our understanding of the role of $\mathrm{NF}-\kappa \mathrm{B}$ family in lymphomas.

\section{Acknowledgements}

We thank Dr Ryuichiro Kimura for excellent assistance and discussion. We express our gratitude to Dr Tatsushi Muta for providing the expression vectors for $\mathrm{I} \kappa \mathrm{B}-\zeta$ and its mutants, and reporter plasmids for IкB- $\zeta$. We also thank Drs Martin Rowe, Toshiki Watanabe, Lionel Larue, Dean W. Ballard, Romas Geleziunas, Kuan-Teh Jeang, Jun-Ichi Fujisawa, Ken-Ichi Yamamoto, Naofumi Mukaida, Timothy W. McKeithan for providing expression vectors for LMP-1 and its mutants; expression vectors for CD30 and its mutant, and TRAF2-dominant-negative mutant; expression vectors for RelA; for I $\kappa \mathrm{B} \alpha$ - and I $\mathrm{B} \beta \beta$-dominant-negative mutants; for NIK-, IKK $\alpha$ - and IKK $\beta$-dominant-negative mutants; for IKK $\gamma$-dominant negative mutant; reporter plasmids for $\mathrm{NF}-\kappa \mathrm{B}$; for IL-6; for IL-8 and AP-1; and for Bcl-3. We acknowledge Dr Takeshi Sairenji for providing B95-8/Ramos. The present study was supported in part by JSPS KAKENHI grant nos. 90542358 and 25461428.

\section{References}

1. Gasparini C, Celeghini C, Monasta L and Zauli G: NF- $\kappa B$ pathways in hematological malignancies. Cell Mol Life Sci 71: 2083-2102, 2014.

2. Carbone A, Tripodo C, Carlo-Stella C, Santoro A and Gloghini A: The role of inflammation in lymphoma. Adv Exp Med Biol 816: 315-333, 2014.

3. Hoesel B and Schmid JA: The complexity of NF- $\kappa$ B signaling in inflammation and cancer. Mol Cancer 12: 86, 2013. 
4. Horie R and Watanabe T: The biological basis of Hodgkin's lymphoma. Drug News Perspect 16: 649-656, 2003.

5. Vockerodt M, Yap L-F, Shannon-Lowe C, Curley H, Wei W, Vrzalikova K and Murray PG: The Epstein-Barr virus and the pathogenesis of lymphoma. J Pathol 235: 312-322, 2015.

6. Kaye KM, Izumi KM and Kieff E: Epstein-Barr virus latent membrane protein 1 is essential for B-lymphocyte growth transformation. Proc Natl Acad Sci USA 90: 9150-9154, 1993.

7. Devergne O, Cahir McFarland ED, Mosialos G, Izumi KM, Ware CF and Kieff E: Role of the TRAF binding site and NF-kappaB activation in Epstein-Barr virus latent membrane protein 1-induced cell gene expression. J Virol 72: 7900-7908, 1998.

8. Izumi KM and Kieff ED: The Epstein-Barr virus oncogene product latent membrane protein 1 engages the tumor necrosis factor receptor-associated death domain protein to mediate B lymphocyte growth transformation and activate NF-kappaB Proc Natl Acad Sci USA 94: 12592-12597, 1997.

9. Schultheiss U, Püschner S, Kremmer E, Mak TW, Engelmann H, Hammerschmidt W and Kieser A: TRAF6 is a critical mediator of signal transduction by the viral oncogene latent membrane protein 1. EMBO J 20: 5678-5691, 2001.

10. Soni V, Cahir-McFarland E and Kieff E: LMP1 TRAFficking activates growth and survival pathways. Adv Exp Med Biol 597: 173-187, 2007.

11. Horie R, Watanabe $\mathrm{T}$, Morishita $\mathrm{Y}$, Ito $\mathrm{K}$, Ishida $\mathrm{T}$, Kanegae Y, Saito I, Higashihara M, Mori S, Kadin ME, et al: Ligand-independent signaling by overexpressed CD30 drives NF-kappaB activation in Hodgkin-Reed-Sternberg cells Oncogene 21: 2493-2503, 2002.

12. Horie R, Aizawa S, Nagai M, Ito K, Higashihara M, Ishida T, Inoue $\mathrm{J}$ and Watanabe T: A novel domain in the CD30 cytoplasmic tail mediates NFkappaB activation. Int Immunol 10: 203-210, 1998

13. Arkan MC and Greten FR: IKK- and NF-кB-mediated functions in carcinogenesis. Curr Top Microbiol Immunol 349: 159-169, 2011.

14. Ryan KM, Ernst MK, Rice NR and Vousden KH: Role of NF-kappaB in $\mathrm{p} 53$-mediated programmed cell death. Nature 404 892-897, 2000

15. Sheehy AM and Schlissel MS: Overexpression of RelA causes G1 arrest and apoptosis in a pro-B cell line. J Biol Chem 274 8708-8716, 1999

16. Kuilman T, Michaloglou C, Mooi WJ and Peeper DS: The essence of senescence. Genes Dev 24: 2463-2479, 2010

17. Schmitt CA: Cellular senescence and cancer treatment. Biochim Biophys Acta 1775: 5-20, 2007.

18. Jing $\mathrm{H}$ and Lee $\mathrm{S}$ : NF- $\mathrm{\kappa B}$ in cellular senescence and cancer treatment. Mol Cells 37: 189-195, 2014

19. Yamazaki S, Muta T and Takeshige K: A novel IkappaB protein, IkappaB-zeta, induced by proinflammatory stimuli, negatively regulates nuclear factor-kappaB in the nuclei. J Biol Chem 276 27657-27662, 2001

20. Muta T: IkappaB-zeta: An inducible regulator of nuclear factor-kappaB. Vitam Horm 74: 301-316, 2006.

21. Yamamoto M, Yamazaki S, Uematsu S, Sato S, Hemmi H, Hoshino K, Kaisho T, Kuwata H, Takeuchi O, Takeshige K, et al: Regulation of Toll/IL-1-receptor-mediated gene expression by the inducible nuclear protein IkappaBzeta. Nature 430: 218-222, 2004.

22. Nogai H, Wenzel S-S, Hailfinger S, Grau M, Kaergel E, Seitz V, Wollert-Wulf B, Pfeifer M, Wolf A, Frick M, et al: I $\kappa$ B- $\zeta$ controls the constitutive NF- $\kappa \mathrm{B}$ target gene network and survival of $\mathrm{ABC}$ DLBCL. Blood 122: 2242-2250, 2013

23. Kimura R, Senba M, Cutler SJ, Ralph SJ, Xiao G and Mori N: Human $T$ cell leukemia virus type I tax-induced IкB- $\zeta$ modulates tax-dependent and tax-independent gene expression in T cells. Neoplasia 15: 1110-1124, 2013.

24. Floettmann JE and Rowe M: Epstein-Barr virus latent membrane protein-1 (LMP1) C-terminus activation region 2 (CTAR2) maps to the far C-terminus and requires oligomerisation for NF-kappaB activation. Oncogene 15: 1851-1858, 1997.

25. Huen DS, Henderson SA, Croom-Carter D and Rowe M: The Epstein-Barr virus latent membrane protein-1 (LMP1) mediates activation of NF-kappa B and cell surface phenotype via two effector regions in its carboxy-terminal cytoplasmic domain. Oncogene 10: 549-560, 1995.
26. Julien S, Puig I, Caretti E, Bonaventure J, Nelles L, van Roy F, Dargemont C, de Herreros AG, Bellacosa A and Larue L: Activation of NF-kappaB by Akt upregulates Snail expression and induces epithelium mesenchyme transition. Oncogene 26 7445-7456, 2007.

27. Motoyama M, Yamazaki S, Eto-Kimura A, Takeshige K and Muta T: Positive and negative regulation of nuclear factor-kappaB-mediated transcription by IkappaB-zeta, an inducible nuclear protein. J Biol Chem 280: 7444-7451, 2005.

28. Brockman JA, Scherer DC, McKinsey TA, Hall SM, Qi X, Lee WY and Ballard DW: Coupling of a signal response domain in I kappa B alpha to multiple pathways for NF-kappa B activation. Mol Cell Biol 15: 2809-2818, 1995.

29. Geleziunas R, Ferrell S, Lin X, Mu Y, Cunningham ET Jr, Grant M, Connelly MA, Hambor JE, Marcu KB and Greene WC: Human T-cell leukemia virus type 1 Tax induction of NF-kappaB involves activation of the IkappaB kinase alpha (IKKalpha) and IKKbeta cellular kinases. Mol Cell Biol 18: 5157-5165, 1998

30. Iha H, Kibler KV, Yedavalli VRK, Peloponese JM, Haller K, Miyazato A, Kasai T and Jeang K-T: Segregation of NF-kappaB activation through NEMO/IKKgamma by Tax and TNFalpha: Implications for stimulus-specific interruption of oncogenic signaling. Oncogene 22: 8912-8923, 2003.

31. McKinsey TA, Brockman JA, Scherer DC, Al-Murrani SW, Green PL and Ballard DW: Inactivation of IkappaBbeta by the tax protein of human T-cell leukemia virus type 1: A potential mechanism for constitutive induction of NF-kappaB. Mol Cell Biol 16: 2083-2090, 1996

32. Aizawa S, Nakano H, Ishida T, Horie R, Nagai M, Ito K, Yagita H, Okumura K, Inoue J and Watanabe T: Tumor necrosis factor receptor-associated factor (TRAF) 5 and TRAF2 are involved in CD30-mediated NFkappaB activation. J Biol Chem 272: 2042-2045, 1997.

33. Yamazaki S, Muta T, Matsuo S and Takeshige K: Stimulus-specific induction of a novel nuclear factor-kappaB regulator,IkappaB-zeta, via Toll/Interleukin-1 receptor is mediated by mRNA stabilization. J Biol Chem 280: 1678-1687, 2005.

34. Suzuki T, Hirai H, Murakami T and Yoshida M: Tax protein of HTLV-1 destabilizes the complexes of NF-kappa B and I kappa B-alpha and induces nuclear translocation of NF-kappa B for transcriptional activation. Oncogene 10: 1199-1207, 1995.

35. Okamoto S, Mukaida N, Yasumoto K, Rice N, Ishikawa Y, Horiguchi H, Murakami S and Matsushima K: The interleukin- 8 AP-1 and kappa B-like sites are genetic end targets of FK506sensitive pathway accompanied by calcium mobilization. J Biol Chem 269: 8582-8589, 1994.

36. Shimizu H, Mitomo K, Watanabe T, Okamoto $\mathrm{S}$ and Yamamoto K: Involvement of a NF-kappa B-like transcription factor in the activation of the interleukin- 6 gene by inflammatory lymphokines. Mol Cell Biol 10: 561-568, 1990.

37. Ge B, Li O, Wilder P, Rizzino A and McKeithan TW: NF-kappa B regulates BCL3 transcription in T lymphocytes through an intronic enhancer. J Immunol 171: 4210-4218, 2003.

38. Mori $\mathrm{N}$ and Prager D: Transactivation of the interleukin-1alpha promoter by human T-cell leukemia virus type I and type II Tax proteins. Blood 87: 3410-3417, 1996.

39. Horie R, Watanabe T, Ito K, Morisita Y, Watanabe M, Ishida T, Higashihara M,Kadin Mand WatanabeT:Cytoplasmic aggregation of TRAF2 and TRAF5 proteins in the Hodgkin-Reed-Sternberg cells. Am J Pathol 160: 1647-1654, 2002.

40. Sylla BS, Hung SC, Davidson DM, Hatzivassiliou E, Malinin NL, Wallach D, Gilmore TD, Kieff E and Mosialos G: Epstein-Barr virus-transforming protein latent infection membrane protein 1 activates transcription factor NF-kappaB through a pathway that includes the NF-kappaB-inducing kinase and the IkappaB kinases IKKalpha and IKKbeta. Proc Natl Acad Sci USA 95: 10106-10111, 1998

41. Hayden MS and Ghosh S: Shared principles in NF-kappaB signaling. Cell 132: 344-362, 2008.

42. Canoz O, Rassidakis GZ, Admirand JH and Medeiros LJ: Immunohistochemical detection of BCL-3 in lymphoid neoplasms: A survey of 353 cases. Mod Pathol 17: 911-917, 2004.

43. Palmer S and Chen YH: Bcl-3, a multifaceted modulator of NF-kappaB-mediated gene transcription. Immunol Res 42: 210-218, 2008 